\title{
THE STATE FINANCIAL REGULATION OF THE PEOPLE'S REPUBLIC OF CHINA SOCIAL AND ECONOMIC DEVELOPMENT PRIORITIES
}

\author{
T. Zhyber \\ $\mathrm{PhD}$, Associate Professor of Chair in Finance \\ Kyiv National Economic University named after Vadym Hetman, Ukraine \\ tzhiber@gmail.com
}

The article is devoted to the examine of the public financial management using by the People's Republic of China Government for the problems of social and economic development solving. Macro finance budgeting as a part of new public management can improve the public funds efficiency applying by arrange them due to the programs. Tax regulation in China and direct funding of government programs are considered. The priorities of the public financial management instruments using in PRC are singled out.

Key words: public financial management, macro finance budgeting, tax regulation, state policy priorities, program budgeting in China

\section{ПРІОРИТЕТИ ДЕРЖАВНОГО ФІНАНСОВОГО РЕГУЛЮВАННЯ СОЦІАЛЬНО-ЕКОНОМІЧНОГО РОЗВИТКУ КИТАЙСЬКОЇ НАРОДНОЇ РЕСПУБЛІКИ}

\section{T. В. Жибер}

Приклад Китайської Народної Республіки (далі - Китай, КНР) показує вчасну переорієнтацію великої за територією та населенням комуністичної країни з моделі суто адміністративної економіки до гібридної соціалістично-ринкової. Політика контролю співіснує із залученням вдалих інструментів 3 ринкової економіки заради розвитку і виживання країни. Незважаючи на комуністичну ідеологію, Китай ухвалив рішення розмежувати політичне життя та економічну діяльність, поставивши за мету розвиток і процвітання власного народу. Головними орієнтирами курсу Китаю 20 років тому стали економічна вигода $\mathrm{i}$ стимулювання запозичення найкращих практик з усього світу. У політичному житті Китай підтримує 10 принципів невтручання і взаємоповаги, сформульованих на Бандунзькій конференції ще в 1955 році. В економічній діяльності країна проявляє далекоглядність, натиск і розрахунок на власну вигоду.

Використання соціалістичної ідеології рівності у справедливому розподілі та жорстких ієрархічних правил суспільного устрою підвищує унікальність управління економічною системою країни та інтерес дослідників до неї. Оскільки країна відзначається вкрай серйозним ставленням до складання i виконання стратегічних планів, КНР можна брати за взірець щодо наполегливості та організованості в досягненні поставленої мети.

(C) 2018 T. Zhyber; Published by the A. Yu. Krymskyi Institute of Oriental Studies, NAS of Ukraine and the Ukrainian Association of Sinologists on behalf of The Chinese Studies. This is an Open Access article distributed under the terms of the Creative Commons Attribution License (https://creativecommons.org/licenses/by-nc-nd/4.0/). 
Метою цієї публікації $є$ виокремлення і систематизація пріоритетів управління державними фінансами в Китаї в контексті розвитку державного публічного менеджменту, одне із завдань якого - попередження та вирішення соціально-економічних проблем. Бюджетування публічних коштів для підвищення ефективності їхнього розподілу та використання - необхідна технологія державного публічного менеджменту будь-якої сучасної розвинутої країни. Поєднання державних фінансів та макрофінансового бюджетування Китаю можна вважати особливим. Країні в останні роки вдається поєднувати адміністративне регулювання економіки та іiі саморегулювання. Тому досвід КНР $€$ вартісним для економістів, соціологів і політологів.

Макрофінансове бюджетування - це технологія, яка передбачає організацію публічних фінансових ресурсів у просторі та управління їхнім рухом у часі. Первинне завдання макрофінансового бюджетування - забезпечення отримання стійкого найкращого результату з можливих і підтримання ефективності публічних (у випадку Китаю найточніше підходить поняття “державних") фінансів. Компонування методів макрофінансового бюджетування та їхнє застосування в кожній окремо взятій країні завжди має свої індивідуальні ознаки та об'єднує такі напрямки діяльності, як державний фінансовий менеджмент і державна соціально-економічна політика.

За даними вчених у публікації Світового банку [Angang 2005, 60], Китай ініціював запровадження ринкових інструментів у свою економіку, починаючи ще з 1978 року. Країна мала значну територію, поділену за етнічними ознаками, потребувала централізованого керівництва для підтримання цілісності політичного об'єднання, але значна централізація в державних фінансах без урахування особливостей регіонів становила, навпаки, загрозу. Використання державних фінансів Китаю середини минулого століття зосереджувалося на отриманні доходів у центральний бюджет завдяки діяльності державних підприємств, де переважала державна власність. Податки становили незначну частину доходів, у 1978 році - лише 45 \% доходів зведеного (центрального) бюджету Китаю. Для порівняння: в Україні навіть у роки великих запозичень податкові доходи забезпечують близько 70 \% доходів зведеного бюджету, а у країні з розвинутою ринковою економікою, без значної залежності від фінансування бюджету податки повинні становити 92-95 \% доходів бюджету.

Централізована модель перерозподілу владних повноважень та фінансових ресурсів тільки “згори донизу” перестала справлятися з вирішенням проблем на місцях. Тому в Китаї із 70-х років минулого століття, спочатку стихійно, почала формуватися місцева влада, а у 1980-х роках центральні партійні лідери взяли процес під контроль та уніфікували його. У 1982 році Конституція КНР визначила місцеву владу базового рівня. Децентралізація врятувала Китай від таких недоліків планової економіки, як невідповідність попиту і пропозиції між агентами, зменшення стимулів до регіонального розвитку тощо. Однак у спадок країна дістала значну соціально-економічну нерівність між міськими і сільськими жителями, з якою бореться до цього часу, визначивши вирівнювання економічного та освітнього потенціалу населення одним 3 основних пріоритетів державної політики на Центральній економічній робочій конференції у 2013 році [Карпунин 2017].

На початку 90-х років XX століття частка доходів бюджету у ВВП впала до $11 \%$. Тому КНР значно змінила ситуацію з оподаткуванням у ХХІ столітті, провівши, на противагу адміністративній децентралізації, фіскальну цен- 
тралізацію у сфері оподаткування заради підвищення його ефективності. Податки уніфікували для всієї країни, скоротили їхнє число і спростили адміністрування. Як показано на рис. 1, частка податків у доходах зведеного бюджету Китаю виросла до рівня країн з розвинутою ринковою економікою у 2003 році, але вже у 2016 році зменшилася до 81,7 \% за рахунок зростання доходів від державного майна і підприємницької діяльності.

\section{Рис. 1. Відсоток податкових доходів у доходах зведеного бюджету КНР}

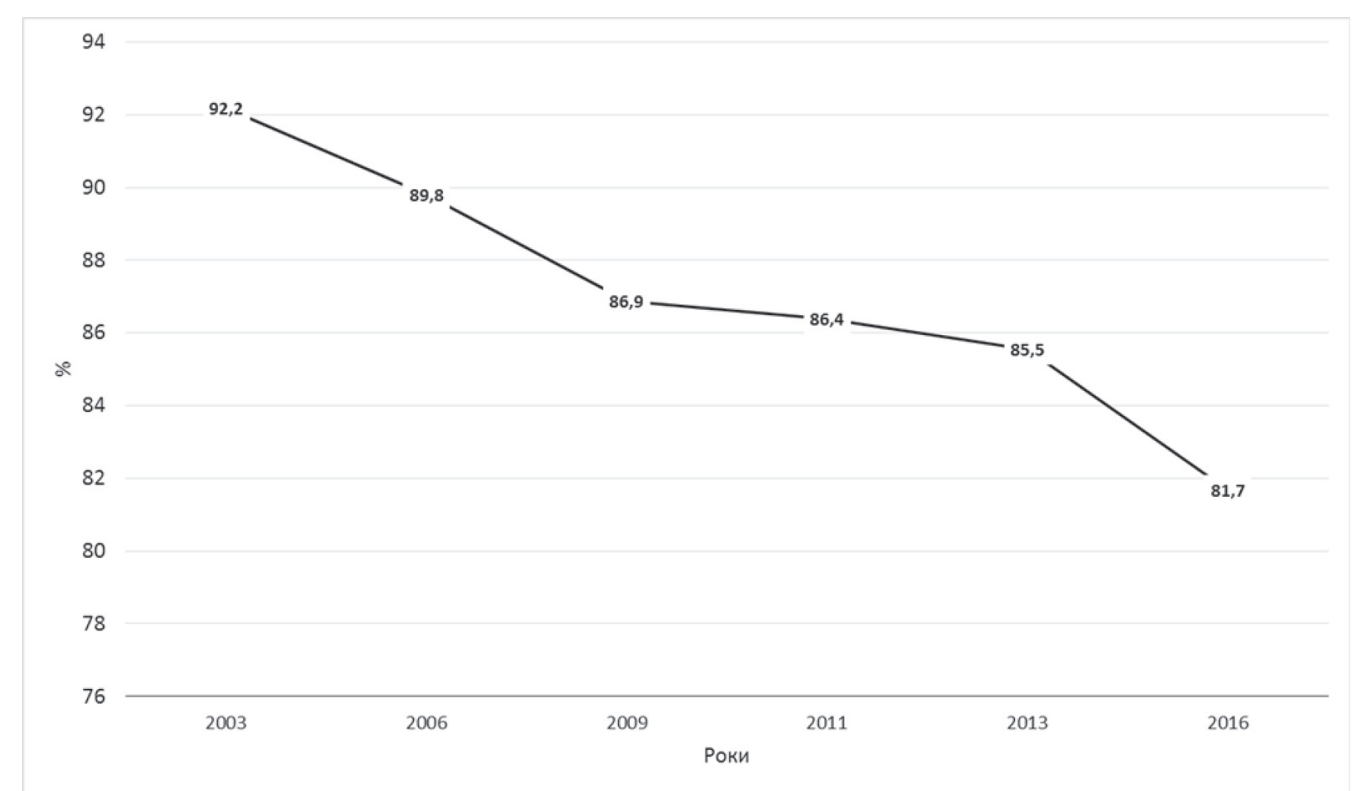

Джкерело: розраховано автором за даними [China Statistical... 2017]

Податки на ведення бізнесу в КНР зробили непрямими. У 2006 році Центральна державна рада скасувала сільськогосподарський податок, найдавніший податок Китаю (по суті данину із селян), щоб підтримати сільські комітети та спільноти, пожвавити сукупний попит як продуктивний чинник зростання ВВП. На той час дохід жителів міст більш ніж втричі перевищував дохід селян, також сільські жителі не мали права на пенсію, не мали доступу до якісної освіти тощо. Цей крок став однією з основних причин стрімкого зростання китайської економіки.

Неподаткові доходи в Китаї у 2016 році переважно формувалися 3 доходів від державної власності і державних програм, значну частку мали виплати бюджетних установ, штрафи та інші доходи. На основі чергової податкової реформи 2018 року можна зробити висновок, що у країні соціально-регулювальна роль податків не менш важлива, ніж фіскальна. Податкові пільги є широко вживаним і дієвим інструментом для стимулювання і спрямування інноваційної діяльності, підтримки малорентабельного стійкого бізнесу тощо. Більшість податків мають кілька ставок для різних груп платників, прямі доходи фізичних осіб оподатковуються за пропорційною ставкою, фокус податкового тягаря впевнено пересувається на кінцеве споживання та люксове майно. У Китаї уряд намагається відстежувати і попереджувати фінансові спекуляції, шахрайство, неліцензовану (неналежно ліцензовану) діяльність тощо. Ці правила не менш жорсткі і для іноземців, хоча загалом політика країни дуже дружня до іноземного співробітництва. 
На рис. 2 показана структура податкових надходжень до зведеного бюджету КНР у 2003 та 2016 рр. згідно із групуванням даних у бюлетені національної статистики Китаю.

\section{Рис. 2. Структура податкових надходжень до зведеного бюджету КНР}

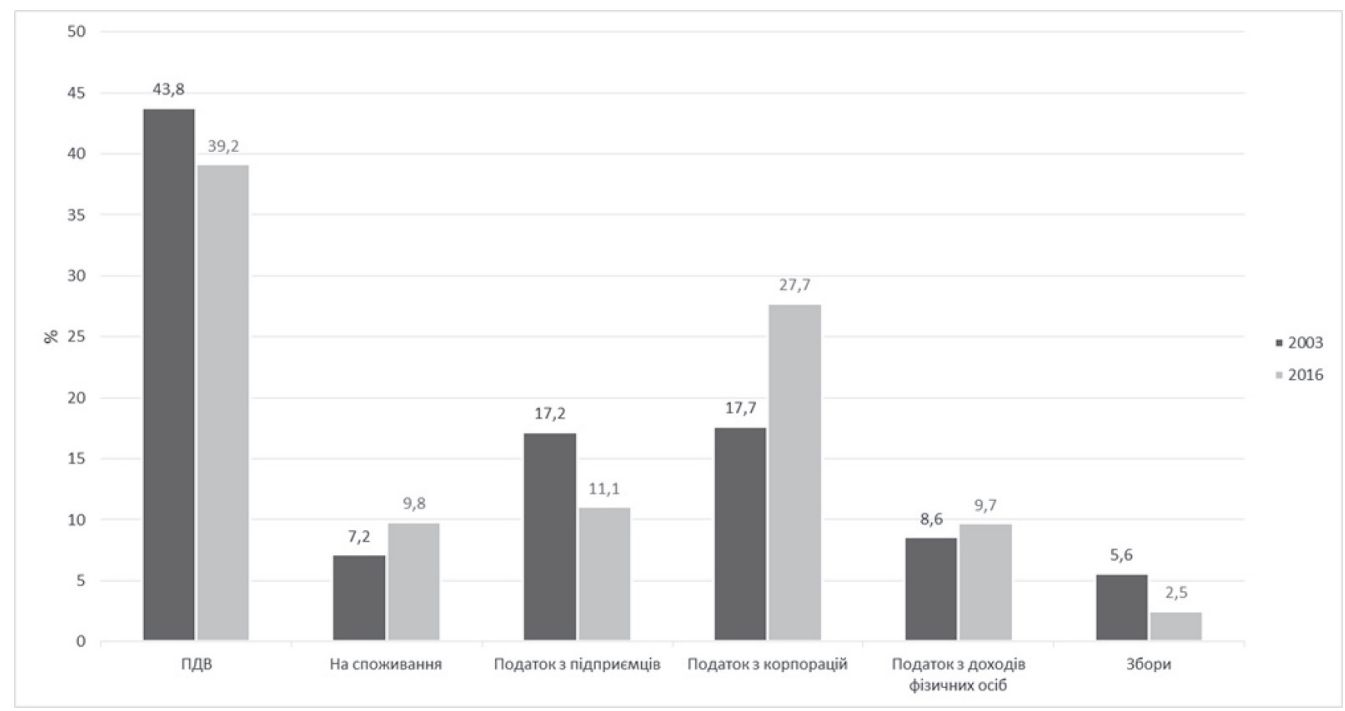

Джерело: розраховано автором за даними [China Statistical ... 2017]

Податок з підприємців у Китаї непрямий, як і ПДВ та податок на споживання. Графік показує, що найбільший фіскальний ефект країна очікує від непрямих податків, а розвиток споживання дає їй змогу покладатися в бюджетних доходах на універсальний акциз - ПДВ. Стандартні ставки ПДВ були зменшені навесні 2018 року, а група платників з бізнесів, що стосуються освіти і будівництва, сплачує цей податок взагалі за ставкою 3 \%. Найменша ставка ПДВ для регіональних послуг 3 надання освіти - 2 \%. Слід зазначити, що підприємства роздрібної торгівлі, готельного, ресторанного, розважального бізнесу, транспорту, логістики, зв'язку та міської інфраструктури сплачують у Китаї ПДВ за ставкою $10 \%$. Також пільги зі сплати ПДВ надані постачальникам фінансових і страхових послуг, підприємствам високих технологій та тим, які надають послуги консалтингу, - ставка ПДВ для них 6 \%. Найвища ставка ПДВ у КНР - 16 \% 31 травня 2018 року. Вона менша, ніж загальна ставка у $20 \%$ цього податку в Україні.

Розрахунок структурних зрушень у податкових надходженнях КНР із 2003-го по 2016 р. більш детально показаний у табл. 1.

Таблиця 1.

Структурні зрушення податкових надходжень КНР із 2003-го по 2016 р.

\begin{tabular}{|l|c|c|c|c|}
\hline $\begin{array}{c}\text { Група податкових } \\
\text { надходжень }\end{array}$ & $\begin{array}{c}\text { Структура } \\
\text { податків у } \\
2003 \text { р., \% }\end{array}$ & $\begin{array}{c}\text { Структура } \\
\text { податків у } \\
2016 \text { p., \% }\end{array}$ & $\begin{array}{c}\text { Зміна структу- } \\
\text { ри податків у } \\
2016 \text { р. порівня- } \\
\text { но 3 2003 p., \%. }\end{array}$ & $\begin{array}{c}\text { Темп росту } \\
\text { групи податків } \\
\text { 2016 p. порів- } \\
\text { нян 3 2003 p. }\end{array}$ \\
\hline ПдВ & 43,8 & 39,2 & $-4,6$ & 89,4 \\
\hline На споживання & 7,2 & 9,8 & 2,7 & 137,4 \\
\hline Податок з підприємців & 17,2 & 11,1 & $-6,2$ & 64,3 \\
\hline
\end{tabular}




\begin{tabular}{|l|c|c|c|c|}
\hline Податок з корпорацій & 17,7 & 27,7 & 10,1 & 157,1 \\
\hline $\begin{array}{l}\text { Податок з доходів фі- } \\
\text { зичних осіб }\end{array}$ & 8,6 & 9,7 & 1,1 & 113,1 \\
\hline Збори & 5,6 & 2,5 & $-3,1$ & 44,8 \\
\hline
\end{tabular}

Джерело: розраховано автором за даними [China Statistical... 2017]

Розрахований за даними табл. 1 квадратичний коефіцієнт абсолютних структурних зрушень (коефіцієнт Козинця) дорівнює 5,46, що свідчить про досить значні наслідки змін через реформи у фіскальній політиці Китаю, які не припиняються.

Зростання частки податку з корпорацій та на майно фізичних осіб і зменшення оподаткування середніх підприємців та іноземних інвестицій з огляду на структурні зрушення у 2016 році порівняно з 2003 роком вказують на прогресивну політику держави за сучасними теоріями ринкової економіки, де податки перекладаються на кінцеве споживання та багатших [Юхименко 2010, 308].

Отже, для регулювання власного економічного середовища ринковими інструментами Китай активно використовує податкові пільги.

За пріоритетними напрямками державного фінансового регулювання податкові пільги в Китаї можна згрупувати так:

- пільги окремим особам для створення середнього класу в умовно сільській місцевості (невеликі за місцевими поняттями містечка) і залучення туди інтелектуальних інвестицій (місцева влада може встановлювати самостійно пільги для дітей селян, які збираються поселитись у містах неурбаністичних регіонів після отримання освіти); збільшення неоподаткованого мінімуму для податку з доходів фізичних осіб до 3500 юанів (прибрали, по суті, оподаткування бідних); прогресивна ставка оподаткування доходів, більших за 50000 юанів - до $35 \%$;

- пільги для підприємств з іноземним капіталом (Китай намагається активно використовувати світові досягнення з перспективних напрямків). Якщо ж таке підприємство експортує більш ніж 70 \% своєї продукції - воно платить лише 10 \% податку;

- пільги окремим регіонам для стимулювання їхнього розвитку і створення зон інновацій та технопарків (із притаманним країні прагматизмом пільги насамперед надаються регіонам, у яких і так справи йдуть потенційно непогано, - інвестиційно і туристично привабливим південно-східним Шенчженю, Шанхаю тощо);

- пільги для стимулювання певної діяльності: інновацій у сфері інформаційних технологій та робототехніки; розвиток енергозбереження та енергоефективності; застосування інших високих технологій за наявності в підприємців сертифіката про високі технології встановленого зразка; пільги для стартапів тощо. У цих випадках податок доходить максимум до 15 \% замість звичайних 25 \% або взагалі встановлюються додаткові податкові канікули;

- пільги з податку для малорентабельних невеликих підприємств (зниження ставки до 20 \%) - це стосується насамперед сімейного бізнесу у сфері харчування тощо;

- пільги при розрахунку податків отримують також підприємства сільського, лісового господарства, риболовні і тваринницькі, залежно від організації їхньої діяльності (стимулювання до бажаної форми діяльності); підприємства 
3 комплексним циклом (переробкою вторсировини, замкненим циклом, технологіями переробки відходів тощо) - стимулювання до комплексного використання ресурсів; підприємства, які встановлюють чи розробляють природоохоронні технології виробництва [Fiscal... 2018, 24-29].

Надалі Китай планує розвивати мережу місцевих (регіональних) податків, щоб зменшити тягар фіскального вирівнювання за допомогою податкової системи та збільшити додаткові можливості розвитку для регіонів.

Наступним важливим стимулювальним інструментом державного фінансового менеджменту є пряма фінансова допомога, що передбачає централізацію і подальше витрачання державних (народних) фінансових ресурсів КНР найбільш ефективно. Державну фінансову підтримку за рахунок публічних фінансів Китаю розглянемо як:

1) допомогу окремим фізичним особам у вигляді адресних цільових субсидій;

2) фінансову та адміністративну допомогу юридичним особам-інвесторам у вигляді стабільних державних замовлень, кредитів під невисокі відсотки, забезпечення місця і інфраструктури для будівництва, сприяння закупівлям тощо.

На рис. 3 показана динаміка співвідношення державного фінансування до ВВП КНР за останні 10 років. Загальні державні витрати розраховані із врахуванням чистого придбання нефінансових активів - землі та інших елементів природного багатства, яке не було результатом процесу виробництва. Отже, в останні роки інвестиції Китаю в основний капітал становлять близько $15 \%$ від ВВП. Витрати кінцевого споживання державного управління Китаю включають витрати на державні замовлення, державні закупівлі, що стосуються індивідуальних та колективних гарантованих та фінансованих державою послуг і належать до фінансового стимулювання соціально-економічного розвитку Китаю за державні кошти. Звісно, державні послуги включають і соціальну сферу, а не тільки сферу інновацій, але підхід до розуміння соціального захисту в Китаї дещо інший, ніж в Україні.

\section{Рис. 3. Частка витрат держави у ВВП КНР}

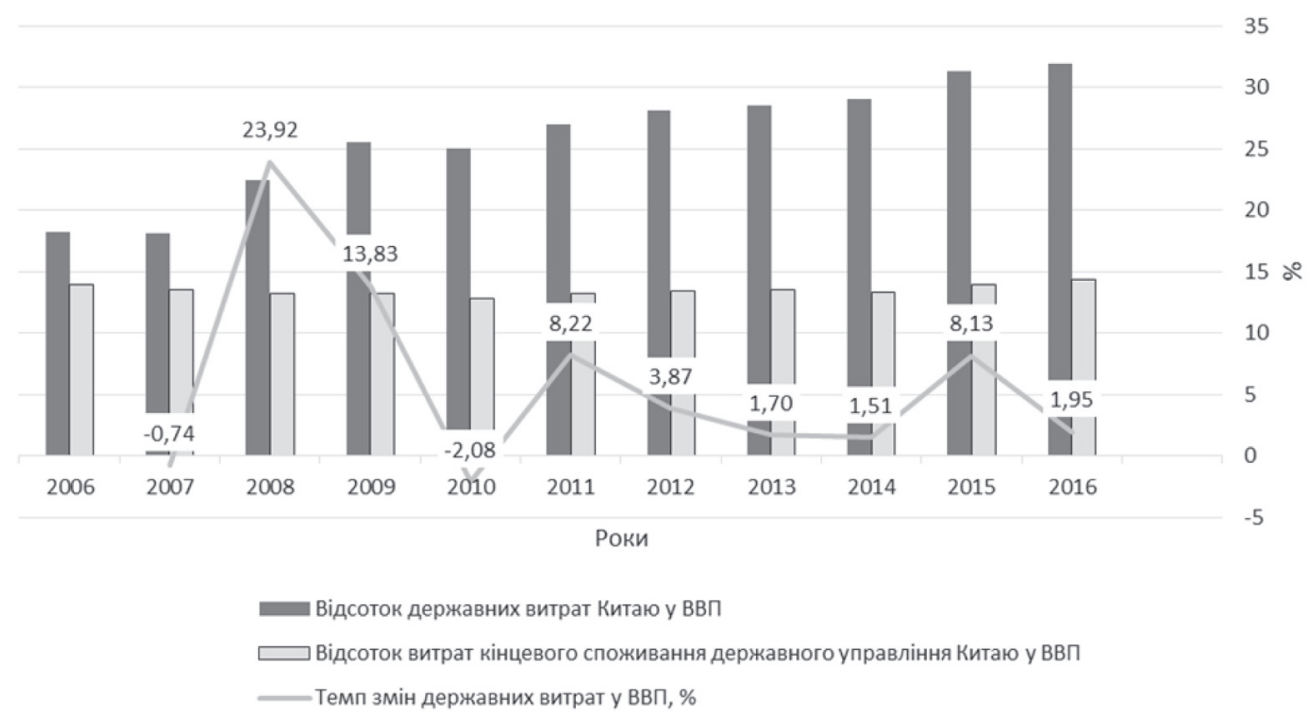

Джерело: складено автором за даними [World data... 2018] 
32014 року до загальної системи обліку запроваджують моніторинг і рейтингове оцінювання кожного громадянина, у яке також інтегрується і фінансова система. Так, низькорейтинговому громадянину, який не старається та порушує закони, не відкриють банківську карту (відмови відбуваються у пілотних провінціях вже у 2018 році).

Слід підкреслити, що в Китаї мало соціальних пільг фінансово забезпечуються таким способом, як в Україні, - прямими знеособленими видатками з бюджету для певної групи. Пільг на кшталт, наприклад, безкоштовного проїзду громадським транспортом всім громадянам певної категорії Китай не надає, а політика контролю за народжуваністю передбачила "пільги" зі здешевлення проживання в селах. Влада давала сім'ям більше землі для обробітку, дозволяла безкоштовно мати будинок тощо.

У табл. 2. згруповані деякі статті державних витрат за видатками розвитку у 2016 році. У Китаї вони не повністю повинні враховуватись у бюджеті, але у статистичній звітності ці частки (бюджетна і позабюджетна) відображаються.

Таблиця 2

Напрямки операційних та капітальних державних видатків КНР y 2016 році

\begin{tabular}{|c|l|l|l|}
\hline $\begin{array}{r}\text { № } \\
\text { 3/п }\end{array}$ & \multicolumn{1}{|c|}{ Призначення видатку } & $\begin{array}{c}\text { Частка від ко- } \\
\text { штів, які відо- } \\
\text { бражаються у } \\
\text { бюджеті, } \%\end{array}$ & $\begin{array}{c}\text { Частка у загаль- } \\
\text { них державних } \\
\text { операційних } \\
\text { видатках, \% }\end{array}$ \\
\hline 1. & Поповнення фонду соціального захисту & 0,5 & 2,7 \\
\hline 2. & $\begin{array}{l}\text { Субсидія на соціалізацію пенсіонерів державних } \\
\text { підприємств }\end{array}$ & 0,7 & 16,2 \\
\hline 3. & $\begin{array}{l}\text { Субсидія на пропозицію житла в містах для змі- } \\
\text { ни місця проживання }\end{array}$ & 15,25 & 1,3 \\
\hline 4. & Модернізація виробництв колективної власності & 11,0 & 41,0 \\
\hline 5. & Капітальні видатки на державні підприємства & 38,3 & 5,6 \\
\hline 6. & Субсидування державних підприємств & 4,2 & 18,7 \\
\hline 7. & Інші видатки розвитку & 9,7 & \\
\hline
\end{tabular}

Джерело: розраховано автором за [China Statistical ... 2017]

У таблиці відображені не всі видатки, вона сформована, щоб показати пріоритети фінансування, відображені в розбіжності у видатках розвитку на соціальний захист пільгових категорій населення та на підтримку виробництва й інфраструктури.

Сьогодні пільги в Китаї окремі фізичні особи можуть отримати тільки за результатами своїх здобутків для загального блага країни: допомога з освітою, допомога з житлом молодим спеціалістам у певних, бажаних для країни регіонах тощо. Однак Китай активно використовує інструменти захисту бідних сімей у вигляді періодичної підтримки від місцевої влади. Пенсії донедавна були передбачені тільки для державних службовців, зараз у Китаї індивідуальні пенсійні рахунки, i, за даними OECD, у 2016 р. пенсійні виплати становили 8,2 \% від ВВП. У Китаї запроваджене медичне страхування, для селян воно коштує близько 60 юанів на рік і покриває до 70 \% медичних витрат. Також активно поширюється користування індивідуальними рахунками громадян, в останні роки населення активно стимулюють відкривати карткові рахунки в банках. 
До 2000 року бюджетна система Китаю складалася з центрального та регіональних бюджетів і вирізнялася хаотично переплетеними взаємозв'язками між міністерствами і бюджетними установами упродовж бюджетного року. Для виділення бюджетних коштів установа не тільки повинна була отримати затвердження постатейних видатків (весь бюджет був постатейним) у свого профільного міністерства, а й отримати дозволи в суміжних установ. Або навпаки, не маючи стосунку до міністерства - не могла претендувати на кошти для виконання певних функцій. Також відбувалася суперечка між установами за планові кошти упродовж року, адже бюджет був негнучким: хто першим встигав пройти інстанції-дозволи, той отримував кошти першим, тому в результаті якісь установи могли залишитись недофінансованими [Wong 2007, 2].

Після 2000 року Китай провів бюджетну реформу, суть якої була у виокремленні ключових міністерств та визначенні їм завдань у межах цільових коштів. Основою є розглянутий і затверджений п'ятирічний план, а також наскрізні бенчмарки - стратегічні багаторічні державні програми як підстави для орієнтиру на пріоритети витрачання державних коштів. 3 цільових фондів, які управляються провідними міністерствами та іншими спеціальними органами центральної і регіональної виконавчої влади, країна фінансує проекти в межах державних програм, сформульованих чітко за стратегічними пріоритетами. Процедура затвердження інноваційних чи капітальних видатків у КНР ретельна і не суб'єктивна. Державні програми Китаю розробляються і фінансуються з огляду на конкретні завдання для розвитку, при цьому КНР вдало, як показав досвід останніх 20 років, визначає напрямки розвитку високих технологій.

У цілому Китай орієнтується на п'ятирічні плани, які узгоджуються “знизу вгору". Китай у визначенні політики витрачання публічних коштів надзвичайно децентралізований як для країни з комуністичною ідеологією. Міста-осередки регіонів розробляють програми і відправляють їх на розгляд дрібніших місцевих комітетів, які усебічно розглядають і компонують різні пропозиції. Далі програми від регіонів пропонуються центральному уряду. Для того щоб юридична особа потрапила у програму-п'ятирічку зі своїм проектом (навіть якщо це іноземний інвестор), слід вести роботу з підготовки пропозиції за програмою інколи тривалістю близько року, отримуючи різноманітні консультації, довідки та висновки аудиторів. При цьому корупційне вирішення проблем у Китаї може мати дуже жорсткі наслідки.

У контексті макрофінансового бюджетування Китай активно використовує цільові фонди як форму організації державних фінансів. У 2016 році у статистичному щорічнику КНР [China Statistical... 2017] було виділено 29 цільових фондів та окремою статтею - групу більш дрібних. Найбільшими за сумами коштів були: Фонд для передачі прав використання державних земель (72\% від суми усіх фондів), Фонд використання траспортних засобів (3,6 \%), Фонд соціального захисту за рахунок проведення лотерей $(2,5 \%)$, Фонд використання доходів від державних земель (2,4 \%). Меншими за обсягом, але цікавими за призначенням - такі: Фонд реконструкції залізничних шляхів, Фонд розвитку туризму, Національний спеціальний фонд розвитку кінематографії, Фонд створення і розвитку нових овочевих полів, Фонд платежів для утилізації сміття з міст тощо.

Нещодавно голова КНР заявив на Загальнокитайських зборах народних представників, що вони відкривають для іноземних компаній додаткові 
можливості в рамках побудови відкритої китайської економіки, зокрема участь у фінансовому секторі та управлінні фондами. Хоча збори закликали іноземних інвесторів вкладати більше капіталу в центральні й західні райони країни та в такі сектори, як сільське господарство, охорона навколишнього середовища, передова обробна промисловість і послуги, на ці напрямки заплановано також близько 553 млрд. юанів державних видатків і водночас планується додати 11 млн. нових робочих місць у 2018 році.

Стратегія “Зроблено в Китаї-2025” - відносно новий (із 2015 року) стратегічний національний план для оновлення циклів промисловості Китаю 3 метою зниження зовнішньої залежності виробництва від технологій, сировини, матеріалів чи комплектувальних. Китай намагається вийти на експорт високих технологій. Метою цієї програми є створення незалежних повних циклів виробництва, і за три роки КНР вже показав телескоп "Небесне око”, швидкісний поїзд “Фусін”, суперкомп'ютер, вантажний космічний корабель та інші продукти. Наприклад, у 2018 році Китай уклав угоду на поставку поїздів до Німеччини. Речники КНР зазначають, що і до іноземних, і до китайських компаній у ході реалізації цієї національної стратегії будуть ставитися однаково. Інвестори також дістануть однаковий доступ до таких сфер, як отримання ліцензій, держзакупівлі, стандартизація та інші [Made in China 2025... 2017]. Водночас Китай стимулює житлове будівництво урбаністичного характеру i розвиває "розумні міста", заявляє про будівництво “міст-садів" з будівель, вкритих деревами, для зменшення викидів вуглецю - основної загрози для навколишнього середовища країни.

У ході фінансування державних програм відбувається і реорганізація державного управління з метою відповідності державних органів поставленим завданням. У березні 2018 року було опубліковане Повідомлення державної ради КНР "Про організаційну структуру” [Уведомление... 2018]. Цим повідомленням Головне державне управління торгово-промислової адміністрації перетворили на Головне державне управління з регулювання ринкової діяльності. Нове відомство буде наділене усіма повноваженнями з регулювання ринкової діяльності, включаючи реєстрацію суб'єктів підприємницької діяльності, контроль якості промислової продукції, безпеку продуктів харчування, контроль за безпекою спеціального обладнання, товарну експертизу, сертифікацію і стандартизацію.

У КНР динамічно змінюються підзаконні акти залежно як від вимог ринку, так і політики країни зокрема. Так, Державна комісія у справах розвитку і реформ Китаю розробляє нове положення про інвестиції в автомобільну промисловість із “більш докладними правилами” щодо вимог до проектів з автомобілями на нових енергоносіях. Поряд зі стрімким зростанням рівня технологій “засобів пересування на нових енергоносіях" (NEV - англ.) і поступовим розширенням ринку з'явилися ознаки безладного розвитку, тому необхідно "запобігти безсистемному будівництву і безладному розвитку", цитує агентство новин Xinhua офіційного представника держкомісії. В останні роки Китай активізував зусилля щодо стимулювання використання автомашин на нових джерелах енергії для ослаблення тиску на навколишнє середовище, пропонуючи податкові пільги і знижки на купівлю автомобілів, що призвело до швидкого зростання продажів і виробництва NEV. Китай залишається найбільшим у світі ринком автомобілів на нових енергоносіях протягом трьох років поспіль [China will... 2017]. 
Для розвитку інновацій, високих технологій та постійного покращення конкурентоспроможності у світі Китай широко використовує державну підтримку наукових ініціатив. Державні програми фінансової та адміністративної підтримки досліджень та інновацій у Китаї згруповані в табл. 3.

Таблиця 3

Сфери державних пріоритетів Китаю щодо досліджень, освіти та інновацій

\begin{tabular}{|c|c|c|}
\hline $\begin{array}{l}\text { № } \\
\text { 3/ח }\end{array}$ & $\begin{array}{l}\text { Орган, який керує } \\
\text { програмами }\end{array}$ & Спрямування і призначення програм \\
\hline 1. & $\begin{array}{l}\text { Міністерство науки та техно- } \\
\text { логій КНР }\end{array}$ & $\begin{array}{l}\text { Національна основна дослідницька програма } 973 \text {; } \\
\text { Національна програма розвитку сучасних технологій } \\
\text { 863; Національна програма основних соціальних пи- } \\
\text { тань та інфраструктури; Ключові проекти, які вклю- } \\
\text { чають сферу біотехнологій, екології, ліків, зв’язку, } \\
\text { кібернетики та енергетики. Окремо існує фонд інно- } \\
\text { вацій у сільському господарстві. }\end{array}$ \\
\hline 2. & $\begin{array}{l}\text { Національний фонд природ- } \\
\text { ничих наук Китаю }\end{array}$ & $\begin{array}{l}\text { Основна програма, яка охоплює всі галузі науки, про- } \\
\text { грама співробітництва між регіонами (окремо виді- } \\
\text { лено фонд для молодих науковців), програма фондів } \\
\text { дольової участі за різними науковими сферами. Про- } \\
\text { грама дольової участі для китайських вчених 3-за } \\
\text { кордону. }\end{array}$ \\
\hline 3. & $\begin{array}{l}\text { Національна академія наук } \\
\text { Китаю }\end{array}$ & $\begin{array}{l}\text { Має програми для вчених (програма Ейнштейна), для } \\
\text { молодих вчених, для вчених з міжнародного обміну. }\end{array}$ \\
\hline 4. & $\begin{array}{l}\text { Стипендіальна рада Китаю - } \\
\text { неприбуткова організація при } \\
\text { Міністерстві освіти Китаю. }\end{array}$ & $\begin{array}{l}\text { Включає програми з ЮНЕСКО, університетських та } \\
\text { урядових стипендій, зокрема для закордонних студен- } \\
\text { тів, підтримку до захисту дисертації для іноземців. }\end{array}$ \\
\hline
\end{tabular}

Джерело: складено автором за [National funding... 2018]

Отже, узагальнюючи висновки щодо сучасної політики державного фінансового стимулювання соціально-економічного розвитку Китаю, можна виокремити такі його пріоритети:

a) стимулювання іноземних інвестицій (фінансових чи інтелектуальних) на першому місці - Китай свідомо залучає технології та ресурси з інших країн, які мають вартісні здобутки;

б) стимулювання конкуренції серед молоді для збільшення інтелектуального потенціалу шляхом створення попиту на освічену молодь та молодь із закордонною освітою (для праці на підприємствах з іноземним капіталом, які перебувають у кращих умовах порівняно з національними підприємствами); розподіл молоді за невеликими містами, щоб уникнути перевантаження мегаполісів;

в) створення пільгових економічних зон у привабливих для іноземних інвестицій місцях із подальшим розвитком і застосуванням високих технологій; щедре фінансування наукових досліджень як співвітчизників у своїх закладах, так і кращих вчених з-за кордону;

г) розвиток відповідальної економіки. Китай намагається створити замкнені цикли виробництва у країні, прагне налагодити експорт продуктів високих технологій китайського виробництва. Влада активно розвиває і стимулює шерингову економіку серед населення, плекає альтернативні види діяльності 
(світ випускає автомобілі на водні - отже, у КНР будують заправні станції, їх вже 23 тощо).

Таким чином, регульована економіка Китаю 3 виваженим використанням системи податкового регулювання та державних програм для розвитку на сьогодні забезпечує йому провідні позиції у світі.

\section{ЛІТЕРАТУРА}

Карпунин В. И. Урбанизация как инструмент повышения благосостояния населения Китая [Електронний ресурс] // Карпунин В. И., Маркова Д. С. Региональная экономика и управление: электронный научный журнал. 2017. № 1. - Режим доступу: https://eee-region.ru/article/4948/

Уведомление государственного совета КНР “Об организационной структуpe” (2018 г.) [Електронний pecypc] // Chinalaw.center. 2018. - Режим доступу: https://chinalaw.center/china_administrative/china_state_council_structure_2018_ chinese/

Юхименко П. І., Федосов В. М., Лазебник Л. Л. та ін. Теорія фінансів: Підручник / За ред. проф. В. М. Федосова, С. І. Юрія. Київ: Центр учбової літератури, 2010.

Angang H. China's economic growth and poverty reduction (1978-2002) // Angang H., Linlin H., Zhixiao C. In India's and China's Recent Experience with Reform and Growth. London: Palgrave Macmillan, 2005.

China Statistical Yearbook 2017 [Електронний ресурс] // National Bureau of Statistics. 2018. - Режим доступу: http://www.stats.gov.cn/tjsj/ndsj/2017/indexeh. htm

China Will Consider Resumption of New Electric Car Permits [Електронний pecypc] // Bloomberg. 2017. - Режим доступу: https://www.bloomberg.com/ news/articles/2017-11-14/china-is-said-to-consider-resumption-of-new-electriccar-permits-j9z5kq65

Fiscal Affairs Dept. People's Republic of China: Tax Policy and Employment Creation. Country Report No. 18/92 [Електронний ресурс] / Fiscal Affairs Dept. // International Monetary Fund. 2018. - Режим доступу: https:/www.imf.org/en/ Publications/CR/Issues/2018/03/28/Peoples-Republic-of-China-Tax-Policy-andEmployment-Creation-45765

Made in China 2025 strategy to drive economic transformation [Електронний pecypc] // english.gov.cn. 2017. - Режим доступу: http://english.gov.cn/news/ top_news/2017/04/16/content_281475628095631.htm

National funding programs in Mainland China [Електронний ресурс] // Access4EU. - Режим доступу: http://www.access4.eu/China/274.php

Wong C. Budget reform in China // OECD Journal on Budgeting. 2007. № 7.

World Data Atlas [Електронний ресурс] // knoema.com. - Режим доступу: https://knoema.com/atlas/China

\section{REFERENCES}

Angang H., Linlin H., \& Zhixiao C. (2005), China's economic growth and poverty reduction (1978-2002). In India's and China's Recent Experience with Reform and Growth, pp. 59-90. Palgrave Macmillan, London.

China Statistical Yearbook 2017 (2018), www.stats.gov.cn. Retrieved from http:// www.stats.gov.cn/tjsj/ndsj/2017/indexeh.htm 
China Will Consider Resumption of New Electric Car Permits (2017), Bloomberg News, Retrieved from https://www.bloomberg.com/news/articles/201711-14/china-is-said-to-consider-resumption-of-new-electric-car-permits-j9z5kq65

Fiscal Affairs Dept. (2018), People's Republic of China: Tax Policy and Employment Creation. Country Report No. 18/92. International Monetary Fund. Retrieved from https://www.imf.org/en/Publications/CR/Issues/2018/03/28/Peoples-Republicof-China-Tax-Policy-and-Employment-Creation-45765

Made in China 2025 strategy to drive economic transformation (2017), english. gov.cn, Retrieved from http://english.gov.cn/news/top_news/2017/04/16/content 281475628095631.htm

$\bar{N}$ ational funding programs in Mainland China. (n.d.). Access4EU. Retrieved from http://www.access4.eu/China/274.php

Wong, C. (2007), Budget reform in China. OECD Journal on Budgeting, 7(1), pp. 1-24.

Karpunin V., \& Markova D. (2017), Urbanizatsiya kak instrument povysheniya blagosostoyaniya naseleniya Kitaya [Urbanization as an instrument for improving China's well-being], Regional'naya ekonomika i upravleniye: elektronnyy nauchnyy zhurnal - Regional economy and management: an electronic scientific journal, 1(49). Retrieved from https://eee-region.ru/article/4948/ (in Russian).

World Data Atlas (n.d.), knoema.com, Retrieved from https://knoema.com/atlas/ China

Uvedomlenie gosudarstvennogo soveta KNR "Ob organizacionnoj strukture" (2018 g.) [Notice of the PRC state council "About the organizational structure" (2018)]. Chinalaw.center, Retrieved from https://chinalaw.center/china_administrative/china_state_council_structure_2018_chinese/ (in Russian).

Yuhimenko P. I., Fedosov V. M., \& Lazebnik L. L. at al. (2010), Teoriya finansiv: pidruchnyk [Finance theory: textbook]. Kyiv: Tsentr uchbovoyi literatury (in Ukrainian).

\section{ПРІОРИТЕТИ ДЕРЖАВНОГО ФІНАНСОВОГО РЕГУЛЮВАННЯ СОЦІАЛЬНО-ЕКОНОМІЧНОГО РОЗВИТКУ КИТАЙСЬКОЇ НАРОДНОЇ РЕСПУБЛІКИ}

\section{T. В. Жибер}

Стаття присвячена вивченню використання урядом КНР державного фінансового менеджменту для вирішення завдань соціально-економічного розвитку Китаю. Як частина сучасного публічного менеджменту макрофінансове бюджетування дає змогу підвищувати ефективність використання державних фінансових ресурсів через їхнє компонування у програми і фонди. Розглянуто податкове регулювання в Китаї та пряме фінансування державних програм. Виокремлено пріоритети застосування інструментів державного фінансового менеджменту в КНР.

Ключові слова: державний фінансовий менеджмент, макрофінансове бюджетування, податкове регулювання, пріоритети державної політики, програмне бюджетування в Китаї

\section{ПРИОРИТЕТЫ ГОСУДАРСТВЕННОГО ФИНАНСОВОГО РЕГУЛИРОВАНИЯ СОЦИАЛЬНО-ЭКОНОМИЧЕСКОГО РАЗВИТИЯ КИТАЙСКОЙ НАРОДНОЙ РЕСПУБЛИКИ}

\section{T. В. Жибер}

Статья посвящена изучению использования государственного финансового менеджмента правительством КНР для решения задач социально-экономического 
развития страны. Как часть современного публичного менеджмента макрофинансовое бюджетирование позволяет повышать эффективность использования государственных финансовых ресурсов путем формирования программ и фондов. Рассмотрены налоговое регулирование в Китае и прямое финансирование государственных программ. Выделены приоритеты применения инструментов государственного финансового менеджмента в КНР.

Ключевые слова: государственный финансовый менеджмент, макрофинансовое бюджетирование, налоговое регулирование, приоритеты государственной политики, программное бюджетирование в Китае

Стаття надійшла до редакиії 29.05.2018 